BULLETIN Bulletin hispanique

HISPANIQUE Université Michel de Montaigne Bordeaux

$113-2$ | 2011

Varia

\title{
La novela en el Memorial Literario (1784-1808)
}

Hacia la configuración de un modelo crítico

María Jesús García Garrosa

\section{(2) OpenEdition}

Journals

Edición electrónica

URL: http://journals.openedition.org/bulletinhispanique/1411

DOI: 10.4000/bulletinhispanique.1411

ISSN: 1775-3821

Editor

Presses universitaires de Bordeaux

Edición impresa

Fecha de publicación: 1 diciembre 2011

Paginación: 549-584

ISBN: 978-2-86781-793-9

ISSN: 0007-4640

Referencia electrónica

María Jesús García Garrosa, «La novela en el Memorial Literario (1784-1808) », Bulletin hispanique [En línea], 113-2 | 2011, Publicado el 01 diciembre 2014, consultado el 19 abril 2019. URL : http://

journals.openedition.org/bulletinhispanique/1411; DOI : 10.4000/bulletinhispanique.1411 


\title{
La novela en el Memorial Literario (1784-1808). Hacia la configuración de un modelo crítico
}

\author{
María Jesús García Garrosa \\ Universidad de Valladolid
}

La publication du Memorial Literario (1784-1808) coïncide avec la meilleure étape du roman dans l'Espagne du XVIII' : ses cinquante deux numéros nous offrent le panorama le plus complet de la production éditoriale à partir d'une double perspective, bibliographique et critique. Le but de ce travail est donc d'analyser l'idée de roman que transmet aux lecteurs cette revue littéraire et la construction progressive d'un modèle de critique narrative.

La publicación del Memorial Literario (1784-1808) coincide con el momento de mayor desarrollo de la novela en España en el siglo XVIII, por lo que sus cincuenta y dos números ofrecen el más completo panorama sobre la producción editorial desde una doble perspectiva: bibliográfica y critica. El objetivo de este trabajo es analizar el concepto de novela que transmitió esta revista periódica y la paulatina configuración de un modelo crítico para juzgar este género.

The publication of the Memorial Literario (1784-1808) coincided with the highpoint in the development of the novel in 18th-century Spain: its 52 volumes offer the fullest panorama of published works from both bibliographical and critical point of view. The present article thus aims at analyzing the concept of the novel that the Memorial literario conveyed, as well as at tracing the gradual creation of a critical model to examine the genre.

Mots-clés : Memorial Literario - Roman - XVIII e siècle - Critique littéraire - Presse littéraire.

Bulletin Hispanique, Tome 113, n 2 - décembre 2011 - p. 549 à 584. 
A LGUNAS publicaciones periódicas españolas del siglo XVIII constituyen una excelente fuente para conocer la novela en ese período. Los anuncios publicados en sus páginas han suministrado los datos más fidedignos para la estimación de la producción impresa, nos han dado información sobre la difusión y la venta de esas obras, sobre sus potenciales destinatarios y sobre ciertos hábitos de lectura; nos han ilustrado acerca de la llegada a España de la novela europea y la renovación que ésta propició en la narrativa nacional. No ha sido menos valiosa la aportación de las reseńas publicadas en la prensa literaria, desde cuya perspectiva hemos conocido los cambios en la estimación de un género que no gozaba del prestigio poético de los géneros considerados nobles. La prensa, en suma, nos ha permitido trazar de manera más precisa la historia literaria de la novela en España en el siglo XVIII.

Los anuncios de la Gaceta de Madrid y del Diario de Madrid han sido los privilegiados en esta atención de la crítica, junto con algún periódico local $^{1}$. Sin embargo, no existe ningún estudio específico sobre la novela en el Memorial literario, periódico del que sí se ha ocupado ampliamente la crítica en lo relacionado con el género dramático ${ }^{2}$. Sin necesidad de insistir en el significado de este periódico en la historia literaria espańola del siglo XVIII, sí convendrá subrayar que el período de publicación del Memorial literario (1784-1808) coincide con el del auge y mayor desarrollo de la novela en

1. Ma José Alonso Seoane da una visión muy general del tema en el apartado «La novela en la prensa» de su capítulo "Parte I. La época de la Ilustración», en Ma Pilar Palomo (ed.), Movimientos literarios y periodismo en España, Madrid, Síntesis, 1997, pp. 63-66. Sobre aspectos o periódicos concretos véanse especialmente los trabajos siguientes: Ma José Alonso Seoane, "La Novela en el Correo Literario de la Europa», en Periodismo e Ilustración en España. Estudios de Historia Social, n 52-53, 1990, pp. 23-28; Pilar Amo Raigón, "Algunas consideraciones sobre la narrativa en Sevilla a finales del XVIII y principios del XIX: El Correo Literario y Económico", en F. García Lara (ed.), I Congreso Internacional sobre novela del siglo XVIII, Almería, Universidad de Almería, 1998, pp. 79-90; Ma Aurora Aragón Fernández, "Narrativa», en Traducciones de obras francesas en la Gaceta de Madrid en la década revolucionaria (1790-1799), Oviedo, Universidad de Oviedo, 1992, pp. 68-107; Ma Jesús García Garrosa, "Publicidad y venta de novelas en España a finales del siglo XVIII», Bulletin of Spanish Studies, LXXXII, 1, 2005, pp. 19-35; Inmaculada Urzainqui, «Anuncios y reseñas de traducciones de obras inglesas en la prensa española del siglo XVIII», en Scripta in Memoriam J. B. ÁlvarezBuylla, Oviedo, Universidad de Oviedo, 1987, pp. 313-332. No menciono aquí aquellos trabajos que se ocupan de la presencia de novelas cortas o cuentos en la prensa.

2. Véanse especialmente los trabajos de Ma José Rodríguez Sánchez de León, «Una poética dramática en las páginas del Memorial Literario (1784-1788)», en Periodismo e Ilustración en España. Estudios de Historia Social, $\mathrm{n}^{\circ}$ 52-53, 1990, pp. 435-443, y las páginas sobre este periódico en su monografía La crítica dramática en España (1789-1833), Madrid, CSIC, 2000; e Inmaculada Urzainqui, "Crítica teatral y secularización: el Memorial Literario (1784-1797)», Bulletin Hispanique, 94, 1992, n 1, pp. 203-243. 
España. Por ello parece de especial interés analizar el lugar que ocupa este género en un periódico que, hasta la aparición de publicaciones como Variedades de ciencias, literatura y artes o Minerva, ya con el nuevo siglo, es el único en el que de manera regular y continua podemos encontrar la doble mirada sobre la novela: la bibliográfica y la crítica.

El objetivo de este trabajo es analizar tanto la presencia de la novela en el Memorial como la manera de acercarse a ella, es decir, la configuración de un modelo de crítica novelística en un periódico que representa de forma paradigmática la evolución del concepto de crítica literaria ${ }^{3}$. El Memorial literario se publicó entre enero de 1784 y mayo de 1808, con sucesivos cierres y reaperturas que marcan tres etapas muy claras en su historia editorial: 17841791, 1793-1797 y 1801-1808. Los nombres que se sucedieron al frente del periódico en estas etapas determinaron también líneas editoriales diferentes, que afectaron tanto a las secciones de la revista como a los contenidos o a la forma de abordar la crítica ${ }^{4}$. Dado que esas tres etapas se corresponden también con tres períodos muy diferenciables en la historia de la novela en España, creo que el mejor método de acercamiento al estudio de este género en el Memorial literario es el que se basa en esa división cronológica, que muestra la evolución tanto de la oferta novelesca como de los modos de enjuiciarla.

\section{Primera etapa (Enero i784-Enero i79i)}

A diferencia de otros periódicos como la Gaceta de Madrid y el Diario de Madrid, que, en lo que afecta a la literatura, cumplían una función de meros difusores de novedades editoriales mediante anuncios remitidos por los editores con fines publicitarios, el Memorial literario tenía más altas miras, como correspondía a un periódico cultural. Sin embargo, la tarea meramente divulgativa de las nuevas publicaciones españolas y extranjeras prevaleció durante bastante tiempo y la esperable actitud crítica en una publicación literaria tardó en manifestarse en el periódico fundado por Joaquín Ezquerra y Pedro Pablo Trullenc. Sabemos que en sus primeros años los redactores no ejercieron una verdadera labor crítica en ningún género, hasta el punto de que los suscriptores escribieron al periódico reclamando una valoración

3. Véase el trabajo esencial de Inmaculada Urzainqui, «La crítica literaria en la prensa del siglo XVIII. Elementos de su discurso teórico", Bulletin Hispanique, 102, 2000, nº 2, pp. 519-559.

4. Sobre los responsables del periódico en sus diferentes etapas véase el trabajo de Inmaculada Urzainqui, "Los redactores del Memorial literario (1784-1808)», en Periodismo e Ilustración en España. Estudios de Historia Social, n 52-53, 1990, pp. 501-516. 
de los escritos y los escritores 5 . Estos primeros memorialistas alegan falta de fuerzas y de conocimientos para ese cometido crítico, que no iban a ejercer además sobre un género como la novela, que carecía de un referente teórico que guiara sus apreciaciones.

La novela no tiene un apartado propio como el teatro y se ubica mayoritariamente en esta primera etapa del Memorial literario en las secciones de «Libros nuevos» o «Libros traducidos». Desde su apertura en enero de 1784 hasta el cierre en enero de 1791 contabilizamos medio centenar de anuncios de novelas, aunque el número de títulos es aproximadamente de la mitad, dado que algunas novelas se publican en partes que tienen anuncios independientes ${ }^{6}$.

¿Qué novelas se mencionan en esta etapa?7 Lógicamente, el grueso de los anuncios-reseña se refiere a novelas del siglo XVIII. Algunas son obras de la primera mitad del siglo, cuya segunda edición es la que se anuncia ahora (Morir viviendo en la aldea y vivir muriendo en la Corte y Madrid por adentro, $y$ el forastero instruido y desengañado ${ }^{8}$. Caso especial es el de La Farfala, que se reseña en abril de 1786 aunque había salido en 1772. El resto de las entradas corresponden a los textos novelescos recientes, los que en la década de los ochenta marcaron en España el tímido inicio del auge de la novela que llegaría en la década siguiente: las colecciones de novelas cortas ( $V o z$ de la naturaleza, las traducciones de las Novelas morales de Marmontel, Colección universal de novelas y cuentos en compendio), las obras novelesco-educativas (Adela y Teodoro o cartas sobre la educación, Las veladas de la quinta, El nuevo Robinsón, Almacén de las señoritas adolescentes), las obras de Teodoro de

5. Véase lo que dicen al respecto Paul-J. Guinard en La presse espagnole de 1737 à 1791. Formation et signification d'un genre, Paris, Centre de Recherches Hispaniques, 1973, pp. 16-18, e Inmaculada Urzainqui, «La crítica literaria...», op. cit., p. 534.

6. Sucedía esto especialmente en las colecciones de novelas, como la Colección de novelas escogidas, compuestas por los mejores ingenios españoles, Voz de la Naturaleza, o las Novelas morales de Marmontel; pero también se dio en novelas extensas publicadas en varias partes, como Eusebio. No siempre se anuncia la salida de todas las partes, como el Antenor, o el propio Eusebio. En otras ocasiones, un mismo anuncio incluye varias novelas, como las de Cervantes.

7. Para esta etapa, como para las siguientes, puede verse el capítulo de Joaquín Álvarez Barrientos «Novela», en Francisco Aguilar Piñal (ed.), Historia literaria de España en el siglo XVIII, Madrid, Trotta, 1996, pp. 235-283, que en la presentación de la producción novelesca del siglo XVIII va dando noticia en casi todos los casos de la existencia de una reseńa en el Memorial literario.

8. La primera edición de Morir viviendo en la aldea y vivir muriendo en la Corte es de 1737 y la de Madrid por adentro, y el forastero instruido y desengañado de 1741. Sendas ediciones de 1784 se anuncian en abril y julio de ese mismo año. Véase Francisco Aguilar Piñal, Bibliografía de autores españoles del siglo XVIII, Madrid, CSIC, tomo V, 1989, p. 874 y tomo IX, 1991, p. 455. 
Almeida que tanto éxito conocerían, con reediciones posteriores (El hombre feliz independiente del mundo y de la fortuna, La mujer feliz dependiente del mundo y de la fortuna), la descendencia dieciochesca del Quijote, en todas sus formas, continuaciones, parodias, etc. (Adiciones a la Historia del ingenioso Hidalgo Don Quijote de la Mancha, La moral de Don Quijote), la novela cercana al poema épico (Antenor), la novela moral (Nuevos juguetes de la fortuna a favor de la inocencia), la novela costumbrista (El instruido en la Corte y aventuras del Extremeño, Visita de las ferias de Madrid), la que combina lo moral con el reflejo de las costumbres de la Corte (Aventuras de Juan Luis) la novela picaresca (El bachiller de Salamanca). Y dos de las grandes novelas del siglo: Eusebio y Aventuras de Gil Blas de Santillana?.

En el apartado de «Libros reeditados» también hay lugar para la novela. Un único anuncio en enero de 1785 da cuenta de la edición por Antonio de Sancha de las obras de Cervantes, que incluye la Galatea, el Persiles y las Novelas Ejemplares. En octubre de 1787 se reseña el Guzmán de Alfarache, editado en Valencia por los hermanos Orga, y en julio de 1788 El Donado hablador, en la edición madrileña de Benito Cano. La Colección de novelas escogidas, compuestas por los mejores ingenios españoles, con novelas de autores de los siglos XVI y XVII, dio lugar a varios anuncios desde diciembre de 1787 hasta el cierre del periódico, en las salidas sucesivas de los relatos que componían los ocho tomos de la colección.

Por fin, al igual que se hacía con obras de otros géneros, el Memorial da noticia de la aparición de novelas en otros países. De hecho, el primer anuncio de novelas del periódico, en febrero de 1784, es el de la Biblioteca universal de novelas de todas las naciones y siglos, escrita en francés y que consta de 112 tomitos $^{10}$. Y en julio 1790 se anuncian la traducción francesa por Le Tourneur de la famosísima Clarissa de Richardson, aún sin traducir al español, y la colección de Historias fabulosas para instrucción de la juventud, igualmente versión francesa de un original inglés ${ }^{11}$.

9. Aunque la condición de novela es bastante cuestionable en alguno de estos títulos, y en otros que se citarán en adelante, incluyo en este repaso de las novelas mencionadas en el Memorial literario las obras que habitualmente se consideran como tales en repertorios bibliográficos y estudios sobre la novela.

10. Se trata de la famosa Bibliothèque universelle des romans, obra periódica publicada entre 1775 y 1789, de cuyas novelas se hicieron numerosas traducciones en español, sobre todo para su publicación de colecciones de relatos o misceláneas. Fue la inspiradora de la Colección universal de novelas y cuentos en compendio, cuyo primer tomo se reseńó en el Memorial en junio de 1790, pp. 234-235. Véase el artículo de Roger Poirier, «An attempt to rehabilitate the novel: The Colección universal de novelas y cuentos en compendio (1789-1790)», Dieciocho, II, 2, 1979, pp. 154-165.

11. Los dos últimos anuncios se hallan en el apartado "Memorias Literarias Extranjeras», 
Como puede verse, he preferido el término «anuncio» a los de «reseña» o "crítica» para aludir al tratamiento que hace el Memorial de las novelas arriba citadas. Como se recordará, los responsables del periódico en su primera etapa se mostraron poco proclives a ejercer la crítica literaria, de tal manera que lo que ofrecen al lector es poco más que un anuncio que informa de la salida de un libro de novela. Entre 1784 y 1791 no hay que buscar en las páginas del Memorial una presentación crítica de la producción novelesca de la década. No hay crítica literaria aplicada a la novela si por tal entendemos «un ejercicio de enjuiciamiento: un análisis de las obras encaminado a valorarlas correctamente, determinando sus elementos más valiosos y desafortunados para que los lectores conozcan su verdadero mérito» ${ }^{12}$. Ya que los periodistas no se sienten competentes para emitir juicios críticos, intentan cumplir con el propósito divulgador del periódico proporcionando a los lectores una información útil con vistas a la posible compra y lectura de las obras que le oferta el mercado. Lo manifiestan muy claramente los propios editores en la «Advertencia preliminar» al Prospecto del Memorial literario en enero de 1791:

Se da razón de los libros que se publican en España, principalmente en la Corte, presentando a los lectores un extracto o idea de su contenido, para que por él se conozca el asunto de que tratan, y el plan de la obra, a fin de que instruido el autor de la materia, vea si le conviene lo que quiere comprar, y no se engańe por la corta idea que suelen ofrecer sus títulos. Alguna vez se ha ańadido alguna ligera crítica; lo cual se continuará en lo sucesivo más frecuentemente. (p. 4)

Eso es lo que encontramos en la primera etapa del Memorial: una somera presentación, en anuncios muy breves, que oriente al lector sobre los contenidos de las novelas anunciadas. De cuán somera y breve puede llegar a ser esa presentación dará cuenta, por ejemplo, el anuncio de El instruido en la Corte y aventuras del Extremeño, novela de Clara Jara, de la que se dice escuetamente: «Figura el autor de este papel a un estudiante que con motivo de instruir a un rústico de las cosas que pasan en la Corte, descubre los abusos de las regatonas, prado, hosterías, mujeres mundanas, etc. " (octubre

que incluye un "Catálogo de las obras más selectas publicadas en el Diario de los Sabios de Paris [Journal des Savants], año 1789" (julio 1790, p. 437). Cito este dato para mostrar que, en lo relativo a la novela, el periódico de Ezquerra y Trullenc está animado por un afán de divulgación bibliográfica similar al de las producciones en otros campos de las ciencias, las artes o las bellas letras, y que su objetivo, en la mayoría de los casos, no iba más allá.

12. Inmaculada Urzainqui, «La crítica literaria...», op. cit., p. 525. 
1789, p. 304). Suficiente para que el lector, guiado por el título, confirme que se trata de una novela costumbrista. En este género, suele ser ésa la orientación de los anuncios: un repaso a los escenarios y ambientes que recorre la novela o el folleto ${ }^{13}$. Otras veces el periodista prefiere dar cuenta del argumento, como en Eusebio: «Su argumento (en la parte que es susceptible) está reducido a que, habiendo salido de Cádiz un bergantín con destino a la Florida... » (agosto 1786, p. 455) ${ }^{14}$. En las colecciones de novelas, los anuncios van indicando los títulos que contiene cada nuevo volumen, con una brevísima indicación de la historia, tomada normalmente del prólogo de la obra; es el caso de Voz de la naturaleza de García Malo o las Novelas morales de Marmontel, cuya presentación puede también destacar el carácter moral de la narración: «El objeto de esta novela es enseñar a los padres nobles y ricos cómo han de portarse con sus hijos, para que sin alucinarse con la esperanza de poseer las riquezas paternas, reciban una educación arreglada y ventajosa» (La escuela de los padres, junio 1788, p. 340). También en las novelas educativas se da alguna indicación de su utilidad, como El nuevo Robinsón, que tiene «estampas alusivas a los principales lances de la historia y una carta geográfica para facilitar el conocimiento geográfico de los países mencionados en ella» (septiembre 1789, p. 55).

Se aparta un tanto de esta línea el anuncio de Gil Blas de Santillana (agosto 1788, pp. 574-577), cuyo comentario sale fuera del texto propiamente dicho para abordar un aspecto de historia literaria: la paternidad de la obra y el hurto de Le Sage a la nación espańola. No hay nada en el comentario del Memorial literario que no esté en el prólogo del padre Isla, pero al menos el planteamiento de esta cuestión da ocasión para una opinión directa de los memorialistas, que en una nota se atreven a aventurar que la obra es una suma de retazos de obras dramáticas y novelescas españolas, lo que confirmaría su origen hispano ${ }^{15}$.

13. Es el caso de los anuncios de Morir viviendo en la aldea (abril 1784, pp. 74-75), Madrid por adentro (julio 1784, pp. 40-41), o Visita de las ferias de Madrid (octubre 1790, p. 192).

14. En la segunda parte de la novela de Montengón, el lector deberá conformarse con «Continúa en esta segunda parte la historia de Eusebio, en que se prosigue dando razón de sus aventuras, viajes, acontecimientos, etc.» (marzo 1787, p. 376). En algún caso el argumento se toma del índice de la obra, como en Adiciones a la Historia del ingenioso Hidalgo don Quijote de la Mancha (julio 1786, pp. 285-286).

15. «Nosotros pensamos que es una obra compuesta de retazos de novelas, comedias y otros escritos españoles con poca mutación en sus originales. El que haya leído las Relaciones del escudero Marcos de Obregón hallará un buen retazo de ellas en el primer tomo de Gil Blas. En el segundo verá disfrazadas algunas comedias, entre ellas la intitulada Todo es enredos amor, y Diablos son las mujeres. El que haya leído más de este género de escritos nuestros hallará con facilidad los retales de esta maula» (agosto 1788, p. 577). También en el anuncio 
Nada hay, como puede verse por esta muestra, de valoración de las obras, ni referencia alguna a sus elementos literarios ${ }^{16}$; ni siquiera hay mención de cómo está hecha la traducción, una cuestión insoslayable en estos años, y siempre presente en este periódico que llevó a gala el ser azote de malos traductores. Y para el lector que quiera crítica y juicios literarios, los memorialistas le indican dónde encontrarla: en el anuncio de las novelas de Cervantes reeditadas por Sancha, se remite a la autoridad de Mayans, y en las novelas del afamado Marmontel, a otra publicación periódica ${ }^{17}$.

Pero no hay que extrañarse. No estaba entre los objetivos del Memorial de los años ochenta el hacer crítica de otras obras que las teatrales, y en las novelas, como en otros géneros, el periódico se limitó a dar noticia de la oferta editorial, en una función no muy distinta de la que ejercían periódicos de información general como la Gaceta o el Diario madrileños. En ese sentido, en su primera etapa el Memorial literario contribuyó con su información bibliográfica y sus tímidos extractos de contenidos a presentar una historia de la novela en Espańa en esta década y a indicar las tendencias narrativas de este tardío renacimiento del género en la España dieciochesca ${ }^{18}$.

Como hemos visto ya, en el último número publicado antes del cierre de 1791 se reafirmaban los responsables del Memorial literario en su propósito meramente orientador de las compras de los lectores, al tiempo que avanzaban su intención de añadir con más frecuencia "alguna ligera crítica». Veremos si esos objetivos se cumplieron en la nueva etapa del periódico.

de Antenor asoma tímidamente su voz: «Por lo que hemos podido ver en la primera parte de esta epopeya, creemos que si llega a completarse con la segunda, será una de las mejores obras en su clase que tenemos en español» (octubre 1788, p. 213).

16. Sólo en el anuncio de la reedición de la Vida y hechos del pícaro Guzmán de Alfarache leemos: «Lo serio y lo grave va mezclado con lo jocoso y ridículo en esta obra; tiene mucho de erudita, y de sentenciosa, y su estilo, bien que lacónico, es bastante castizo, puro y a veces elegante» (octubre 1787, p. 347). No creo que sea casual el se trate de una novela antigua.

17. «No juzgamos necesario detenernos en dar idea de estas obras, que el lector puede ver en la Vida de Cervantes escrita por Mayans que suele ponerse en las nuevas ediciones de la Historia de D. Quijote» (enero 1785, p. 28). En cuanto a las Novelas morales del autor francés: «Para hacer juicio de estas novelas, se tendrá presente la carta tercera del Censor de París al de Madrid, en donde hace examen de ellas" (octubre 1787, p. 338).

18. A decir verdad, pocas más novelas se publican en los ańos ochenta que las mencionadas en el Memorial literario: Micromegas (1786), El tío Gil Mamuco (1789) o Nueva colección de novelas ejemplares de Martínez Colomer (1790). 


\section{Segunda Etapa (Julio i793-Diciembre i797)}

La última década del siglo XVIII es el momento de esplendor de la novela en España, que se manifiesta en un crecimiento notable de la producción, debida, entre otras causas, a la llegada de las grandes novelas europeas, y en el desarrollo no sólo literario sino también comercial del género. Aumenta la oferta, la variedad de títulos y de géneros novelescos. ¿Tienen estas circunstancias una repercusión en la presencia de la novela en esta nueva etapa del Memorial literario y en el tratamiento crítico que recibe?

No hay más anuncios-reseña de novelas que en el período anterior, pero sí se aprecia una considerable extensión de los mismos y el papel creciente que se va dando en ellos al elemento crítico. Para empezar, la atención del periódico se centra en las novelas de esta década de los noventa; sólo se anuncia una reedición de los Siglos de Oro, la Diana de Montemayor ${ }^{19}$, y tampoco se da noticia de novelas publicadas en otros países europeos.

Se anuncia una veintena de títulos, además de las entregas sucesivas de las dos versiones de la miscelánea de Mme de Gomez, Journées amusantes (Días alegres, de Gaspar Zavala y Zamora, y Jornadas divertidas, de Baltasar Driguet), que incluyen un buen número de novelas, así como el único tomo de otra miscelánea, El no sé qué por no sé quién. El número de anuncios supera esa cifra lógicamente, porque estamos en esta década ante las grandes novelas, vendidas por suscripción y que van saliendo por tomos; en general el Memorial permanece atento a este proceso editorial y va reseñando las sucesivas entregas de novelas como Pamela, Clara Harlowe, El subterráneo o la Matilde, entre otras ${ }^{20}$.

La renovación narrativa de estos años se plasma también en los anuncios. Se reseñan varios géneros: la novela moral (El engaño feliz), la moralcostumbrista (El tiempo de ferias o Jacinto en Madrid), la moral-educativa (Anales de la virtud, Historia de la Baronesa de Bateville), la didáctica con

19. La Diana fue editada por Villalpando en 1795. Su reseña en el Memorial en julio de 1796 (pp. 402-403) se centra en aspectos de historia literaria, con una exposición de la obra del autor, el éxito en el siglo XVI de La Diana, que impuso un modelo narrativo muy imitado después, las ediciones de la novela en los siglos XVI y XVII, sus traducciones, y los elogios que recibió en el Laurel de Apolo.

20. Un indicio de que el periódico va cediendo en su orientación bibliográfica en favor de la crítica es que a veces, en novelas muy extensas, la mención de la aparición de los tomos es irregular. Por ejemplo, se reseńa la salida de los tomos 1 y 2 de Clara Harlowe (diciembre 1794); el siguiente anuncio (noviembre 1795), corresponde a los tomos 5 y 6 , saltándose la salida del 3 y el 4 , y sin mencionar ya los que faltan hasta el tomo 11 que completó la novela. 
fondo histórico (Eudoxia), la sentimental (El Alcázar de la sensibilidad $o$ los matrimonios felices). Siguen vigentes la huella quijotesca en secuelas del texto cervantino (Historia del más famoso escudero Sancho Panza), o en obras paródicas de las costumbres (Historia fabulosa del distinguido caballero D. Pelayo, Infanzón de la Vega, Quijote de la Cantabria), así como la estela de Lesage (Genealogía de Gil Blas de Santillana y El bachiller de Salamanca, o aventuras de D. Querubin de Ronda), o el ya anticuado romance heroico ( $\mathrm{La}$ Casandra). Pero estamos ante el triunfo incontestable de la novela inglesa: a esta etapa del Memorial corresponde la reseña de las obras de Richardson, Pamela y Clara Harlowe, de los Viajes del capitán Lemuel Gulliver, de Swift, de Amelia Booth, de Fielding, de El subterráneo o la Matilde, de Sophia Lee. Y no faltan las colecciones, como la Colección de novelas escogidas o anécdotas sacadas de los mejores autores de todas las naciones, o las Pruebas del sentimiento, traducción de las Épreuves du sentiment, del prolífico Baculard d'Arnaud, de la que sólo se reseña el primer volumen.

Son todas publicaciones de esta década de 1790, aunque algunas se reseñan con cierto retraso, especialmente títulos de 1792 (Genealogía de Gil Blas, El bachiller de Salamanca, Anales de la virtud, La Casandra). Quizá los memorialistas quieren recuperar alguna de las novelas aparecidas durante su época de cierre, entre febrero 1791 y junio de $1793^{21}$.

Las ausencias son esta vez más señaladas que en la etapa anterior, y no toda la producción novelesca de esta década encuentra eco crítico en el Memorial literario. En algunos casos puede atribuirse a falta de tiempo, pues las novelas aparecidas a lo largo de 1797 probablemente no pudieron ser tenidas en consideración antes del nuevo cierre del periódico en diciembre de ese año, dada la abundante oferta editorial de esos meses. Pero extraña, por ejemplo, que no se reseñe otra de las grandes novelas inglesas traducidas en esta década: Tom Jones, de Fielding, vista la atención que presta el periódico a la narrativa británica y el interés que despertó su autor entre el público español; ni El Deán de Killerine, cuyo autor, Prévost, también fue de los más elogiados en la prensa española ${ }^{22}$.

A pesar de que faltan otros títulos muy significativos de la historia de la novela en esta fructífera década de $1790^{23}$, se percibe el esfuerzo de los

21. Son varias las novelas publicadas en esos dos años largos que no tuvieron repercusión en el Memorial, algunas traducciones: La verdadera historia de Inés de Castro (1791), Cartas de una peruana (1792), Memorias para la historia de la virtud (1792), Los dos Robinsones, o aventuras de Carlos y Fanny (1792); otras originales: El Valdemaro (1792), y El Rodrigo (1793).

22. La Gaceta de Madrid publicó los prospectos de suscripción de El Deán de Killerine y Tom Jones en junio y agosto de 1796 respectivamente.

23. No está, por ejemplo, Carolina de Lichtfield, una de las novelas más apreciadas por 
responsables del Memorial literario por ofrecer a sus lectores una información actualizada de las novedades editoriales en el campo de la narrativa. Desbordados, quizá, por una producción muy superior a la de la década anterior, dedican atención a lo que pueden abarcar las páginas de la revista y el trabajo de sus redactores. Queda ahora por ver cómo se enfrentaron éstos a esa producción renovada y mucho más variada que la presentada en la primera época del periódico.

Aunque tras la muerte de Trullenc el periódico cedió en su dinamismo cultural, no parece que eso afectara a la novela. Al contrario, Ezquerra y sus colaboradores se muestran más interesados por ella. Quizá es la importancia que ha ido adquiriendo el género, el notable aumento de las obras publicadas, el peso de los títulos que llegan de Europa y el prestigio incontestable de sus autores, lo que va haciendo tomar a los periodistas conciencia de la importancia de un género que está logrando una acogida popular semejante al teatro, y es por tanto igualmente apto para convertirse en escuela de costumbres y para difundir mensajes renovadores en la sociedad española. Un género, en suma, al que conviene prestar atención no sólo por sus valores literarios, ya asumidos en el resto de Europa, sino tambiém por su ya incuestionable incidencia en la vida pública.

Por otro lado, también se aprecia cómo quienes escriben en el Memorial literario van asumiendo cada vez más claramente la labor crítica respecto a la novela. Sirva de ejemplo el final de la reseña de la Historia fabulosa del distinguido caballero D. Pelayo, en que, tras concluir que la novela divierte pero no instruye, escribe el reseñador:

En un siglo ilustrado en que la moral filosófica ha hecho progresos inmensos, creeríamos incurrir en la nota de una ignorancia estúpida si omitiéramos este ramo de censura, que en otros tiempos apenas

\footnotetext{
la crítica en otros periódicos, y seguramente por el público, pues tuvo dos ediciones, la de 1796 y otra en 1802. Tampoco tuvo eco la Colección de cuentos morales, de Saint-Lambert, traducidos y editados por Francisco de Tóxar en 1796, ni otras colecciones, como la Colección de novelas extranjeras de las más exquisitas y raras (1795) o Experimentos de sensibilidad -otra traducción de Epreuves du sentiment (1795-1799). El Mirtilo (1795), de Montengón, y otra novela pastoril, la Estela, del apreciado Florian, en las dos versiones, ambas de 1797, de Casiano Pellicer y Vicente Rodríguez de Arellano, también se quedaron sin reseñar. Lo mismo sucedió con algunas novelas de tanto éxito como las inglesas Luisa o la cabaña en el valle (1797) y La huerfanita inglesa (1797), o una de las novelas educativas de la prolífica Mme Le Prince de Beaumont, La nueva Clarisa (1797). Falta igualmente reseña de El triunfo de la amistad y el amor más firme y tierno (1796) y Fin funesto de la infidelidad (1796), y de la miscelánea Las noches de invierno (1796-1797), del que sería futuro redactor del Memorial, Pedro Ma de Olive, aunque sí se da noticia de su publicación, en el número XI, de diciembre de 1801, s.p., en el apartado «Anuncios de libros», cuando ya Olive es responsable del periódico.
} 
sería notable. Por esta causa suplicamos al autor disimule, por causa de nuestro oficio, todo cuanto aquí decimos acerca de sus defectos, asegurado de que sólo deseamos que las costumbres se corrijan, y que se quiten los abusos que tanto perjudican a la sociedad (diciembre 1793 , p. 394$)^{24}$.

La crítica, con todo, es muy desigual, sin duda porque sale de plumas diferentes y también, probablemente, porque las exigencias de la divulgación bibliográfica impusieron un ritmo de reseńas que no siempre permitía dedicarle a un texto toda la atención que requeriría; y así vemos que mientras unos críticos han leído a fondo la novela y se toman su espacio para un análisis detallado, otros despachan la reseńa reproduciendo el prólogo de la edición o apelando a lo que han dicho otros críticos de la obra, sin añadir ninguna estimación propia.

Dentro de esta variedad, podemos establecer, de entrada, que los anuncios de esta etapa del Memorial se presentan ya bajo la forma de lo que denominamos reseña, en la que hay dos elementos: el llamado extracto y la parte propiamente crítica. En ambas partes, la descriptiva y la valorativa, el reseńador se enfrenta al enjuiciamiento de obras de un género que carece de un referente teórico, por lo que el análisis se ajusta a los métodos y las categorías procedentes de otros géneros, sobre todo el teatro, repasando la estructura, los caracteres, el estilo, la moral, etc. ${ }^{25}$. El periódico no ofrece todavía en esta década de 1790 pasajes de las obras reseñadas, ni se adentra, salvo tímidas incursiones, en terrenos propios de la historia literaria, como referencias a la vida de los autores o consideraciones teóricas o históricas sobre el género novelesco ${ }^{26}$.

Como he avanzado, en bastantes casos la noticia que da el Memorial literario de las novelas recién publicadas se limita a una paráfrasis del prólogo, cuando no a una reproducción total o parcial del mismo ${ }^{27}$, lo que

24. Sobre esta cuestión, que afecta a los compromisos y legitimidad de la crítica, véase Inmaculada Urzainqui, «La crítica literaria...», op. cit., pp. 533 y $541-545$.

25. Sobre la estructura de la reseña periodística, y las peculiaridades de la crítica de los géneros sin lugar en las poéticas, véanse especialmente las pp. 525, 540 y 548-555 del riguroso trabajo de Inmaculada Urzainqui, varias veces citado, «La crítica literaria...».

26. La reseña de los dos primeros tomos de Jornadas divertidas (febrero 1794, p. 207) incluye una pequeña referencia bio-bibliográfica de la autora francesa, Mme de Gomez. Véase también lo dicho en la nota 19 sobre la reseña de La Diana.

27. Es el caso de las reseñas de Pruebas del sentimiento (febrero 1796, pp. 274-275), Sara Th. (marzo 1796, pp. 390-391), Pamela (agosto y noviembre 1794, pp. 266-268 y 277-283) y Clara Harlowe (diciembre 1794, pp. 338-343), entre otras. 
marca una línea de continuidad con la etapa anterior del periódico en la que sus responsables no entraban en la valoración directa y personal de las novelas anunciadas. Otro tanto podemos decir de aquellas reseńas cuyo redactor transcribe los comentarios de otros críticos: el juicio que puede leerse en la reseña de El Bachiller de Salamanca es el del Abate Desfontaines sobre el original de Lesage (marzo 1796, pp. 385-386), y lo mismo sucede con los «romances del inglés Richardson», Pamela y Clara Harlowe, que son elogiados en la pluma del Abate Andrés o de textos ingleses que figuran en los varios paratextos que acompañaron la edición de las novelas.

Frente a esta actitud, tenemos buenos ejemplos del ejercicio crítico personal en las reseñas de la Vida de Perico del Campo, la Historia de D. Pelayo o los Viajes de Gulliver, de la que hablaré más tarde. En los dos primeros casos, llama la atención que los reseñadores aluden más o menos directamente a una «línea editorial», diríamos, de compromiso del periódico con la verdadera crítica literaria.

La reseña de la Vida de Perico del Campo (diciembre 1793, pp. 394-397) empieza con la ya habitual paráfrasis del prólogo donde el editor explica la peripecia literaria de esta obra «restituida a su idioma original por un buen español», como precisa el título, y justifica el trabajo del traductor para que el trasiego lingüístico no afecte al texto en sus valores estilísticos, su coherencia narrativa y su idoneidad moral para la lectura aun entre "las doncellas más honestas y recatadas» (395). Pero esta vez el memorialista se compromete en un juicio sobre la novela, y toma la voz para valorarla: «Mas nosotros, ajustándonos al instituto de nuestro periódico, debemos decir sin hacer agravio al autor del Perico que su obra fue excelente, y tal vez de las mejores que se escribieron en sus tiempos, y digna seguramente de los mayores elogios, si se compara con las otras obras de esta clase que se escribieron en su edad» (396). Sus méritos literarios (la novela está «bien dispuesta, ordenada, tejida, hablada, etc.») no eliminan, sin embargo, su sabor antiguo y el peligro que supone su tema amoroso: «Todo el asunto del Perico está reducido a un casamiento, y por tanto a mil enredos de amores, varias suertes, desdichas, etc. hasta llegar al cabo.¿Quién es capaz de contar el número de las desdichas, calamidades y ruinas que esta especie de escritos romancescos, fábulas, \&c. han traído al estado, a la patria, y a la religión?» (397).

También la reseña de la Historia de D. Pelayo, Infanzón de la Vega es prueba de un acercamiento crítico más directo a la novela. En el comentario de la primera parte de la obra el memorialista ofrece al lector una presentación detallada del objetivo de esta novela quijotesca: combatir los prejuicios sobre el concepto de nobleza, tema absolutamente pertinente en la sociedad 
española de la época. Y emite un juicio que, aunque muy general, no deja de valorar sus aciertos literarios:

El estilo es bastante culto, y ya que no llegue al del Cervantes en su Quijote, es no obstante muy natural y sencillo, y acomodado a los caracteres de las personas. No deja de pintar bien y con bastante decoro cualquier lance y aventura que ocurre en toda la historia, la cual está tejida de episodios graciosos, y de novelas placenteras, mezclando en ella la amenidad con variedad que instruye al paso que deleita (julio 1793, pp. 46-47).

En la reseña de la segunda parte el periodista se muestra más crítico: «En todo concuerda con la primera: el hilo de la historia está bien seguido, y los hechos admirablemente enlazados. Sólo quisiéramos que en todos estos se encontrara algo más adentro la reflexión filosófica [...]. En efecto, no basta deleitar: es preciso instruir; y esta instrucción en semejantes obras conviene sea moral, a fin de que el lector animado del buen ejemplo abrace el bien incomparable de la virtud y se arme de odio contra el vicio, aborrezca el error y ame la verdad» (diciembre 1793, p. 391). Además de la consideración de la novela como medio de instrucción moral, lo que quiero destacar ahora es que el periodista hace estas afirmaciones -véase el párrafo entero citado más arriba- apoyándose en una concepción ética de la crítica, cuyo objetivo es contribuir a «que las costumbres se corrijan, y que se quiten los abusos que tanto perjudican a la sociedad» (p. 394).

La parte meramente descriptiva de los contenidos de la novela, en una síntesis más o menos extensa del argumento, constituye todavía el cuerpo de bastantes reseńas ${ }^{28}$, pero, como hemos visto, el elemento valorativo va ganando terreno. Conscientes de que se espera de ellos crítica, y de que deben repasar los elementos literarios que están acostumbrados a valorar en las piezas teatrales, los reseńadores proceden a este examen, más voluntarioso

28. El resumen del argumento ocupa en la reseña de Eudoxia seis páginas, dejando apenas dos para el comentario (julio 1793, pp. 35-42). En las novelas en varios tomos de salidas sucesivas, el comentario crítico, si lo hay, suele reservarse para la primera entrega, limitándose en las restantes a contar a los lectores cómo siguen desarrollándose los acontecimientos narrados; véanse, por ejemplo, los dos anuncios de Clara Harlowe, en diciembre de 1794 y noviembre de 1795. También merece ser citada la «reseńa» de los tomos 2 y 3 de El subterráneo o la Matilde, porque constituye la negación de la labor reseńadora y crítica: "Cuando dimos el extracto del tomo $1^{\circ}$ nos alargamos cuanto juzgamos suficiente para poner en noticia del público esta obra. Ahora sólo decimos que estos tomos $2^{\circ}$ y $3^{\circ}$ no son de menos importancia que el $1^{\circ}$. En ellos, pues, el autor aclara y desenreda poéticamente muchos pensamientos curiosos y de suma importancia que allá quedaron pendientes, y se manifiesta de un modo admirable todo el enlace, trama, discurso, orden, etc.» (noviembre 1795, pp. 211-212). 
que efectivo, pues queda en ocasiones reducido a mera enumeración: «En esta novela se observa un bello y exacto plan, invención, pinturas muy vivas y animada locución» (El Alcázar de la sensibilidad, o los matrimonios felices, julio 1793, p. 42). Algo más amplio es el examen de Eudoxia, aunque no más preciso, porque podría aplicarse sin temor a errar a la valoración de cualquier novela: «El plan de esta novela está bien dispuesto y ordenado; los episodios son aptos y oportunos, y bien enlazados entre sí; la solución muy natural y sencilla, el lenguaje puro, propio y correcto, y el estilo igual y animado. El deleite principal resulta de la instrucción y doctrina» (julio 1793, p. 40). Con todo, el comentario es muy ilustrativo de cómo quienes se disponen a enjuiciar la novela en el siglo XVIII lo hacen adecuando sus apreciaciones a unos cauces críticos normativos, repasando los conceptos poéticos que la novela toma prestados de otros géneros, en especial la comedia y la epopeya ${ }^{29}$.

La reseña de novelas como Pamela o Clara Harlowe ofrece otro modelo de crítica. Se trata, como ya he señalado, de juicios que se toman prestados de otros críticos y que presentan al lector una estimación menos normativa de estas producciones. Las novelas de Richardson son, por otro lado, dos de los más genuinos ejemplos de esa nueva novela que ha cambiado el panorama narrativo europeo, y requieren un nuevo acercamiento crítico. Por ello, lo que se destaca de estas novelas es su capacidad para analizar los sentimientos y para reflejar las relaciones sociales. Y así leemos reflexiones sobre el uso de las cartas, que permite que «las pasiones del corazón se hallen retratadas en ellas casi al vivo", o que favorece las expresión de las emociones de forma más viva, directa y espontánea; sobre el realismo de la novela frente al romance: «pues como el autor no saca ninguna de sus bellezas de la imaginación de un espíritu romancesco o novelero, de aquí es que será siempre estimado de las gentes sensatas y de buen gusto", y sobre el interés que propicia ese realismo: «Los caracteres, las pasiones, todo está tomado del centro de la sociedad, todo manifiesta el curso general de las cosas que nos rodean, todo es verdadero, todo real, nada quimérico ni imaginario, nada se encuentra que descubra al autor, y la ilusión se introduce en el ánimo por más estudio y reflexiones que se hagan para evitarla». Las largas reseñas de estas dos novelas hablan de decoro, de «las obligaciones de la vida civil», de los lazos «de una amistad racional e ilustrada entre dos personas sensibles», de los efectos en el ánimo de una lectura emocional y empática «que penetra hasta los más secretos senos del corazón, y le agitan y conmueven sin que pueda resistirlo. El

29. Sobre este trasvase de categorías críticas, véase José Checa Beltrán, Razones del buen gusto (Poética española del Neoclasicismo), Madrid, C.S.I.C., 1998, pp. 200-265, además de las páginas de I. Urzainqui ya citadas en la nota 25. 
espíritu se siente elevado con sublime rapidez, e insensiblemente se encuentra empeñado en el interés de las materias que trata, y toma parte en ellas como si íntimamente le tocasen». De los valores, en suma, de estas novelas que son «cuadros interesantes» de una nueva sociedad en la que está imponiéndose un nuevo concepto de moral ${ }^{30}$.

En la misma línea, aunque pueda parecer paradójico, se encuentra la reseña de los Viajes del capitán Lemuel Gulliver. La novela pertenece al género de la literatura de viajes imaginarios, como los Viajes de Enrique Wanton, Micromegas, y el Viaje a la luna de Cyrano de Bergerac, con las que el comentarista la emparenta; por ello se detiene sobre todo en cuestiones de verosimilitud. De esa aparente desconexión con la realidad que algunos podrían achacar a este viaje imaginario, por el hecho de que «las ficciones de que se vale [el autor] sean quiméricas» (febrero 1794, p. 217), el crítico extrae el fin y la enseñanza de esta novela: «De todo saca imágenes agradables, alusiones y reflexiones: abre los ojos al conocimiento de los vicios enormes que estamos acostumbrados a mirar, cuando más, como unos ligeros defectos, y nos pone delante el precio de una razón pura, y más perfecta que la nuestra. Por último, une las dos calidades de deleitar y aprovechar» $(218)^{31}$. La desconexión con la realidad no es, pues, un mero artificio literario, como lo es en obras del pasado plagadas de elementos o personajes inexistentes (qué decir de los centauros, tritones, pegasos o gorgonas de la mitología), sino una manera diferente de acercarse a la realidad contemporánea, una suerte de realismo visto a través de una lente deformadora que permite, desde la distancia, mirar más de cerca el mundo presente, la sociedad contemporánea.

Como era de esperar, la valoración final de las novelas la determina su utilidad moral, y no sólo porque, dada la situación de la novela en España en este final del siglo, con una censura cada vez más rigurosa, todos se apresten a garantizar (los autores, traductores o editores) o reconocer (los críticos) los valores morales de cada nuevo título. La nueva novela que ha ido imponiéndose a la tradición barroca o clasicista se caracteriza por su condición intrínsecamente moral, en cuanto se presenta como una reflexión sobre las conductas éticas en el plano privado y en el civil.

De esta realidad tenemos también algunos buenos ejemplos en las reseñas que publica el Memorial literario en la década de los noventa. Ya en la primera reseńa de la nueva etapa, la de Eudoxia, se insiste en las lecciones

30. Tomo estas citas de las reseñas de Pamela y Clara Harlowe en noviembre y diciembre de 1794 , ya citadas.

31. Buena parte de las apreciaciones de esta reseña están tomadas del «Prefacio del traductor francés», el Abbé Desfontaines, que figura en el primer tomo de la traducción española de la novela: Viajes del Capitán Lemuel Gulliver, [Madrid], Benito Cano, 1793, pp. VI-XXX. 
de filosofía moral que proporciona su lectura: «Una de las máximas de educación que aquí sobresale es la instrucción de las labores mujeriles, el destierro de preocupaciones caseras, y la enseñanza de la filosofía moral, para que conociendo el falso engaño de las pasiones, se sepa discernir entre los bienes aparentes y la sólida virtud y felicidad. Son muy apreciables y llenas de solidez las instrucciones de filosofía moral que da a Eudoxia su aya Domitila» (julio 1793, p. 41). Muy significativa también es la crítica de Amelia Booth, en la que no hay ni extracto del argumento ni mención alguna de sus valores literarios. La reseña se inicia con: «En esta historia se ven los diversos accidentes que sucedieron a dos dignos esposos después de su unión con los estrechos lazos del matrimonio» (marzo 1796, p. 400), y a partir de ahí el reseñador se lanza en dos largos párrafos a reflexiones morales sobre las desgracias y los accidentes de la vida, y sobre la actitud de quienes deben afrontarlos con prudencia y virtud, para concluir que «las historias del género de ésta pueden con razón pasar por modelos de la vida humana” (401). La ficción novelesca se revela así como «el medio más propio para instruirnos en la más útil de todas las artes, que el autor llama arte de la vida» (401-402).

Otro tanto puede decirse de El Alcázar de la sensibilidad, una novela cuyo valor moral para la juventud radica en que en ella se presenta la repercusión en lo personal y en lo social de una elección acertada o errónea de consorte:

Los jóvenes de ambos sexos y de todas calidades pueden mirarla como un ejemplo de su buena suerte en las elecciones de sus matrimonios. [...] Se describen las pasiones de amor que por sus caminos regulares, guiadas de los objetos de interés y honor, trastornan la felicidad de toda la vida, desgracian los matrimonios, las sucesiones, los hijos, la educación de éstos y su subsistencia, disipan los bienes paternos y acaban con las familias. El amor bien dirigido por su verdadera sensibilidad engendra el más apacible reposo del alma. De aquí nace la inocencia de las costumbres, y la fe conyugal constante de los matrimonios (julio 1793, pp. 42-44).

Es decir, la novela ofrece un tratamiento del tema amoroso acorde con las pautas requeridas por la censura para la publicación de una novela en esta década en Espańa, pero que también se corresponde con el modelo familiar que garantiza la paz y el orden social, como el que mostraron tantas obras teatrales que en estos mismos años debatían sobre la cuestión matrimonial.

En una década en la que el grueso de la producción novelesca es importada, era esperable que el Memorial literario se pronunciara sobre el controvertido asunto de las traducciones. Sin embargo, como en la etapa anterior, vuelve 
a sorprender la discreción en este terreno de una publicación tan combativa en el género teatral contra el fácil recurso al material extranjero. Además de dos breves comentarios a la calidad de la traducción, en La Casandra y Los viajes de Gulliver ${ }^{32}$, la única referencia al respecto hay que buscarla en la 'Introducción' al tomo VII, de enero de 1795. En el repaso de las secciones que tendrá el periódico en adelante, se llega al apartado de libros traducidos, momento en el que inevitablemente se topa el memorialista con la avalancha de traducciones que sufre la literatura nacional: "Pocos años ha todo lo que se traducía era místico; ya no se traducen sino novelas y romances: parece que en esta parte hay modas, como en los adornos. No despreciamos algunas de ellas, pues a la verdad están llenas de instrucción y moralidad, pero en esto de novelas es menester mucho discernimiento» (enero 1795, p. 6).

En realidad, a quien escribe estas páginas sólo le interesa la novela si sirve para corregir y enmendar las costumbres, como la que practicó Cervantes, y si educa, como las de Montengón ${ }^{33}$. No parece la opinión generalizada de cuantos reseñaron novelas en la segunda etapa del Memorial literario, que muestran un abanico más abierto de opciones en que la novela, nacional o extranjera, puede servir como lectura útil para la instrucción moral. Importa, en cualquier caso, que las obras de la década de oro de la novela en la España dieciochesca fueron ganando espacio en el periódico, y fueron presentadas desde una perspectiva más iluminadora que la meramente bibliográfica. La propia evolución de la novela ayudó, sin duda, a conformar unas pautas críticas necesarias en un género que no tenía referentes poéticos propios, y propició un discurso que, sin salirse de los más puros cánones neoclásicos, empezaba a tener en cuenta la especificidad del género narrativo al finalizar el siglo. Todavía estamos lejos de un enfoque crítico que buscara establecer un canon del buen gusto también en la novela y educar en él a los lectores. Quizá esa fue la tarea de la nueva generación de críticos que llegó al Memorial con el nuevo siglo.

32. En ambos casos a los reseñadores les parece que las traducciones adolecen de precipitación y de estilo poco limado.

33. «Es cierto, como hemos insinuado ya, que algunas de las traducidas tienen estas preciosas dotes, y entre las no traducidas y modernas hay otras originales de nuestros españoles, como las del exjesuita Montengón. El Eusebio educa a un joven en el sufrimiento de los trabajos, la mortificación de sus pasiones, y la necesidad de sobreponerse a la inconstancia de la fortuna; la Eudoxia educa a una joven de ilustre prosapia puesta en peligros y trabajos, y el mérito del sufrimiento; el Antenor educa a un príncipe, y amaestrándole en las artes políticas le demuestra que la paz es la mayor felicidad de un reino, y al contrario la guerra la más triste desventura» (enero 1795, p. 7). 


\section{Tercera etapa (Marzo i 80 i-Diciembre i 806) ${ }^{34}$}

El cierre del periódico durante tres años deja sin posibilidad de reseña un buen número de novelas, las publicadas durante 1797 que, como vimos, no tuvieron cabida en los últimos números de ese año, y las aparecidas en 1798, 1799 y 1800. Entre ellas se hallan obras de tanto éxito como Las aventuras de Telémaco, en la versión de Covarrubias (1797-1798), o Pablo y Virginia (1798), además de la tercera novela del inefable Richardson, Carlos Grandisson (1798) ${ }^{35}$.

Cuando se inicia la tercera etapa del periódico han cambiado muchas cosas, en lo relativo a la configuración del mismo y a la novela. Por un lado, se ha hecho cargo del Memorial literario el polifacético Pedro María de Olive, que da nuevo impulso a las reseńas de géneros no teatrales, y que está más claramente interesado en la novela que sus predecesores. Por otro lado, la prohibición de novelas ha puesto cierto freno al desarrollo de un género que había cogido un impulso extraordinario en la década precedente.

Entre 1801 y 1806 hay menos reseñas de novelas, pero su extensión y su calidad son muy superiores. Una docena de novelas se reseña ${ }^{36}$. Es cierto que la producción novelesca se vio mermada por la normativa que desde mayo de 1799 prohibía admitir manuscritos de novelas para su censura, pero en esos años las prensas estamparon más títulos de los reseñados ${ }^{37}$. Sin embargo, parece que las ausencias hay que atribuirlas a razones diferentes a las de las épocas anteriores. Ezquerra y Trullenc tenían muy claro, como hemos concluido, el lugar de la novela en su periódico, y aunque la valoración de

34. No hay más reseńas de novelas a partir de esta fecha, por lo que no contemplo los números que salieron en 1808, tras el nuevo cierre del periódico durante 1807.

35. Sin reseñar también quedaron Carita y Polidoro (1797), La Leandra (1797-1807), Alejo o la casita en los bosques (1798), El principe de Abisinia (1798), Los enamorados, o Galatea y sus bodas (1798), El cariño perfecto (1798), primera edición de La Serafina que sí se reseñará más adelante, La filósofa por amor (1799), o La presidenta de Turvel (1799). También algunas colecciones de novelas u obras misceláneas, como las Nuevas novelas de Florian (1799), Recreaciones y desahogos del hombre sensible (1798), Biblioteca entretenida de las damas (1798), o La Noche entretenida (1798).

36. Hay reseña también de dos misceláneas, El Ramillete o los aguinaldos de Apolo, que mencionaré más adelante, y el primer volumen de Las conversaciones de mi viaje, de Félix Enciso Castrillón (noviembre 1805, pp. 241-255).

37. Puede contabilizarse al menos otra docena de títulos, entre los que destaca Adelaida o el triunfo del amor (1801), Cornelia Bororquia (1801), Memorias de Blanca Capello (1803), Lidia de Gersin (1804), Mis pasatiempos (1804), Historia de Bruce y Emilia (1806), Don Quijote con faldas (1808). 
las novelas fuera adquiriendo más importancia con los años, su objetivo casi exclusivo era dar cuenta de las novedades editoriales y orientar en la compra de las mismas detallando los contenidos.

Vamos a ver en las páginas que siguen que la visión cultural que tienen Olive y sus sucesores es distinta, y eso marca en este período una línea editorial diferente en todo el periódico, lo que afectará también al lugar y al tratamiento de la novela ${ }^{38}$. Olive no da prioridad a la tarea bibliográfica, no quiere presentar toda la producción novelesca, sino seleccionar aquello que le interesa y ofrecer una reseńa más detallada. Algunas reseńas de esta época llevan su firma y la de José María de Carnerero, dos hombres de letras en el sentido más pleno, dos traductores, que se enfrentan a la novela desde unos conocimientos y una actitud que no son los de los voluntariosos Ezquerra y Trullenc. Serán críticas absolutamente personalizadas, en las que vemos, primero, la elección del texto reseñado, y luego su opinión, no la aplicación casi mecánica de una plantilla de análisis de validez general.

No sólo cambia su manera de enjuiciar la novela, sino las formas en que la narrativa se presenta en el periódico. Por un lado, se acentúa la inclusión de fragmentos del texto en la reseńa; por otro irá en aumento el número de cuentos que se publican. Finalmente, en esta última etapa del Memorial habrá lugar para reflexiones sobre la novela y sobre sus autores, sobre sus modalidades y logros, en una tendencia a ofrecer capítulos de una historia literaria cada vez más frecuente en la prensa literaria de la época, y desde luego muy notoria en el Memorial literario.

Es cierto que cuando se inicia la nueva etapa, la actitud programática del periódico en relación con la novela no parece haber cambiado mucho con respecto a épocas anteriores. Así, en la 'Introducción' al primer número de 1801, que expone el Plan de este periódico o Discurso sobre los conocimientos humanos (pp. 1-13), no hay ni rastro del género novela; ni siquiera es mencionada al final del texto, cuando se señalan los temas o géneros (poesía, teatro, historia civil, historia literaria, y otras) de que se ocupará la publicación en esta nueva etapa.

La práctica de los nuevos memorialistas desmiente pronto esta impresión. Las primeras páginas después de la citada 'Introducción' incluyen una Idea del siglo XVIII (pp. 14-44), en la que se repasan los logros del siglo que acaba de terminar en todos los campos; al llegar al terreno de las bellas letras, esta vez sí, aparecen las novelas:

38. La configuración del periódico cambia en estos años, y la ubicación de las reseñas de novelas es variable, pero hay que destacar que ya no se sitúan en el apartado bibliográfico, sino en otros de epígrafes tan significativos como "Literatura española. Novelas», "Análisis literarios», o «Crítica». 
Hay también otros varios géneros de composiciones poéticas y literarias que han sido como inventadas o perfeccionadas en el mismo siglo, pero en las unas las bellezas originales están manchadas con los defectos que hemos notado en la literatura en general, y las otras son por sí de tan mediano mérito que nunca podrán entrar en paralelo con las que sobresalen en el XVII.

En los siglos anteriores la Italia, y en especial la España, habían cultivado con feliz suceso varios géneros de novelas y cuentos, ramo de literatura estimado de los antiguos y de los modernos, hecho muy superior entre éstos, y cuyo mérito es tanto mayor cuanto a veces la más profunda instrucción se oculta bajo el florido aparato de la diversión y el pasatiempo.

Algunos literatos extranjeros no han dejado de observar que los españoles, que pasan por una de las naciones más graves y serias, han sido no obstante los que mayor y mejor número de novelas y cuentos satíricos, burlescos y festivos han producido, bastando el Quijote para darnos la palma en este género.

Las novelas arregladas no nacieron en Francia hasta el tiempo de Luis XIV, y aun sólo sobresalieron entonces las amorosas, pues el Telémaco, género particular y nuevo, no pertenece propiamente ni a la novela ni a la epopeya, debiendo ocupar un lugar distinguido entre los dos.

Las novelas y cuentos morales y filosóficos se deben principalmente al siglo XVIII, y a la nación inglesa. Cervantes puede muy bien por esta parte ser comparado a Fielding, y aun le aventaja; pero ¿qué novelista será comparable con Richardson, el Homero, digámoslo así, de las novelas?

Al mismo tiempo que muchos excelentes autores han perfeccionado esta parte de la literatura tan útil como agradable, ¿cuántos y cuán irreparables dańos no ha causado tanto al buen gusto como a la sana moral el torrente de absurdas e infames novelas que han inundado la Europa, sobre todo en estos últimos tiempos en que han llegado a ser la lectura de preferencia de un vulgo ignorante y preocupado? (pp. 40-41).

Es una breve historia de la novela. En ella, sin abandonar la idea ya canónica de que la edad de oro de la novela espańola se situó en Cervantes y su siglo ${ }^{39}$, se reconoce ya el mérito de la novela contemporánea (la europea, por cierto, que no se dice nada de la espańola). Todo el pasaje es sintomático

39. En esta tercera etapa no se reseńan ya reediciones de novelas de los Siglos de Oro. Caso aparte es la cobertura que dio el periódico a la publicación en 1805 del Anti-Quijote, de Nicolás Pérez, a la que me referiré más adelante. 
de un cambio con respecto a la novela, en el que sin duda ha tenido mucho que ver la consideración del género en el plano teórico y su inclusión en preceptivas como las de Blair y Batteux, traducidas precisamente en estos ańos, o en otros textos sobre la novela no vertidos al espańol, como los de Marmontel o Sade, pero que sin duda conocían quienes escribían en el Memorial.

Observemos otro detalle de la mayor importancia: la aparición del concepto «vulgo ignorante», asociado tradicionalmente al teatro, y aplicado ahora a los lectores de la creciente oferta novelesca. Este último párrafo es indicio de una nueva actitud y unos nuevos objetivos de la crítica en relación con la novela, cada vez más cercanos a los practicados durante décadas en el género dramático: tarea de la crítica será educar al vulgo ignorante en las pautas del buen gusto novelesco ${ }^{40}$.

El nuevo tono y rumbo de la crítica de la novela en esta tercera etapa quedan patentes desde el primer tomo. La primera reseńa es de una novela no traducida aún en España: Herman y Dorotea de Goethe, en una muestra de lo que será uno de los intereses más claros del Memorial en esta etapa: divulgar en España noticias del estado actual de la literatura alemana ${ }^{41}$. En enero de 1805, en un apartado "Literatura Alemana», se incluye una Noticia de una novela de Kotzebue, titulada: Villians [sic] y Juanita (pp. 137-144). La novelita tampoco tenía versión española, pero su anuncio sirve para mostrar las dotes narrativas de uno de los dramaturgos más conocidos en España gracias a sus exitosos dramas, todavía en cartel desde su clamorosa irrupción en 1800 con Misantropia y arrepentimiento. El memorialista elogia los méritos de la novela («tiene todo el mérito de una perfecta sencillez, ya en la fábula, ya en los incidentes, ya en la naturaleza de los caracteres», 137) y hace lo que es técnica habitual en estos años: traducir y ofrecer «un pasaje, que puede servir para que se decida de su género y de su estilo» (138). Al año siguiente, en abril de 1806, un nuevo epígrafe «Literatura Alemana» da paso a un resumen, esta vez muy extenso y presentado en dos partes (abril 1806, pp. 129-143 y mayo 1806, pp. 150-160), de la novela Las víctimas de la magia, o los misterios de la revolución de P..., cuya singularidad radica en el tema, pues «En vez de una intriga amorosa con sus incidentes comunes de celos, obstáculos y riñas, sólo se halla una invectiva perfectamente seguida contra la creencia de la magia, y todas las supersticiones populares» (129).

40. Sobre este texto puede verse el riguroso análisis de José Checa Beltrán, «"Idea del Siglo XVII": Sobre la Ilustración en el Memorial Literario (1801)», Revista de Literatura, vol. LXXI, $n^{\circ} 142,2009$, pp. 497-524.

41. Abundan en estos años noticias de Alemania en todos los campos; en el literario, hay frecuentes reseñas y extractos de poemas, obras dramáticas, históricas, periódicos, etc. 
Pero volvamos a 1801, al inicio de la tercera etapa. En ese mismo primer tomo tras Herman y Dorotea, de la que se elogia su capacidad para pintar las costumbres domésticas, objeto de estas "producciones nuevas»" ${ }^{42}$, le llega el turno a la colección de novelas Lecturas útiles y entretenidas que Pablo de Olavide, bajo el seudónimo de Atanasio Céspedes y Monroy, había empezado a publicar en 1800. La reseña es breve, pero de enorme interés: primero porque el crítico manifiesta sin ambages su mala opinión sobre la labor como escritor y traductor de Olavide; y segundo por el tono en que lo hace.

Esta obra es una colección de novelas, sacadas en la mayor parte de novelistas extranjeros y nacionales, como confiesa el autor en el prólogo. Todas ellas son de poco mérito en cuanto a su plan, caracteres y moral; y en lo que toca a su lenguaje aseguramos de todas veras que son pésimas. ¡Santo Dios, qué lenguaje! Si el autor hubiese poseído la gracia de la buena locución, hubiera encubierto con ella sola los defectos del asunto y de su imaginación, porque el buen lenguaje es indispensable en la novela como en toda poesía. Pero la musa en esta parte no le trató como dice Horacio que trató a los griegos.

Dos cosas hay que notar particularmente en estas novelas. La primera es que lo que tomó de las extranjeras está lastimosamente estropeado, como puede verse en la Ernestina de Mma. Riccoboni, que siendo una joya preciosa, según expresión del literato La Harpe, la truncó, deshizo y paró tal nuestro autor, que en su libro se convirtió en carbón y suciedad.

Reparamos en segundo lugar en que se propongan estas novelas como objeto de entretenimiento y utilidad. ¿Quién podrá llevar esto con paciencia? Hay algunas obscenas, como la del Pintor Velázquez; hay otras de pernicioso ejemplo, como Los peligros de Madrid; hay en fin otras que en vez de inspirar la despreocupación y cultura inspiran todo lo contrario. ¿No nos bastaba la infinidad de novelas que últimamente se han traducido a nuestra lengua para pervertir las ideas y costumbres por las lecciones de falsa sensibilidad, y por la indulgencia y tolerancia con que enseñan a mirar los vicios? (1801, tomo I, p. 65)

He transcrito la reseńa completa porque sirve de muestra del nuevo talante con el que se afronta la crítica literaria de la novela. El tono personal y directo con el que se redacta (lejos ya de la oficialidad de la crítica de los años anteriores) evoca al de la crítica teatral, en la que los críticos del

42. 1801, tomo I, p. 13. Creo que hay que entender el comentario como una constatación del cambio de orientación y contenidos de la nueva novela en Europa. 
Memorial se habían esmerado desde su creación; y lo recuerda también su apreciación, en la que se percibe ya -como vimos en el pasaje de la Idea del siglo XVIII citado arriba- esa concepción novedosa de una crítica que debe constituirse en difusora del buen gusto también en las novelas, y que por eso rechaza por igual a los escritores de poco talento en este género como a esos productos extranjeros de calidad cuestionable que inundan las estanterías de los lectores españoles como han hecho desde hace décadas con los escenarios patrios.

La segunda edición de La Serafina se reseña en el tomo III de 1802, y es igualmente indicativa de la nueva actitud ante la novela. Firma la crítica un R., a quien la novela de Mor de Fuentes no le parece especialmente interesante ni en el asunto, ni en la estructura, ni en la pintura de los caracteres; sin embargo, con fino criterio literario, compartido por toda la crítica posterior, valora su estilo: «se hallan en ella conocimientos literarios, cierta sensibilidad y naturalidad agradable, y sobre todo un lenguaje que, si bien no carece de defectos, se conoce es imitado de nuestros mejores autores, particularmente del inmortal Cervantes» (1802, tomo III, p. 176). Y añade: «Sobre este punto quisiéramos llamar la atención del público: el estudio continuado de las buenas obras comunicará siempre a los escritores así la pureza del lenguaje y las demás cualidades del estilo, como un verdadero gusto en el arte de escribir; y este medio es también el único capaz de levantar nuestra lengua del lastimoso estado a que se halla reducida». Una reflexión tantas veces aplicada en el siglo XVIII a los géneros nobles en la que vemos el paulatino acercamiento a una crítica que, ahora también en el terreno de la novela, va asumiendo el doble objetivo de orientar a los lectores y educarles en el buen gusto y de ayudar al escritor en su tarea compositiva: es decir, «ofrecer pautas de lectura al lector y pautas de escritura al escritor» ${ }^{43}$, algo particularmente difícil cuando se trata de un género para el que no ofrecían reglas las poéticas al uso.

Para que el lector juzgue por sí mismo de los méritos del estilo de esta novela, el reseńador cita un pasaje de la misma. No es la primera vez que el Memorial recurre a este tipo de material. En el número XII de ese mismo año de 1802 (pp. 94-95) aparece la reseña de la miscelánea El Ramillete o los aguinaldos de Apolo, que reúne novelas, cuentos y otros textos escogidos de autores extranjeros. La reseña une la indicación de los contenidos con una cierta valoración de la obra, pero el grueso de la misma lo ocupa una selección de chistes y anécdotas que se ofrecen "para que sirva de muestra al lector, al mismo tiempo que amenicen nuestra obra» (94). El Memorial

43. Inmaculada Urzainqui, «La crítica literaria...», op. cit., p. 529. 
confirma así una de las tendencias habituales en la prensa literaria de estos años: insertar pasajes de la obra reseñada con una clara voluntad antológica, que se irá acentuando en los números siguientes.

No hay reseńas de novelas en los números de 1803, y las de 1804 vienen marcadas por el sello inconfundible de Pedro María de Olive, autor de tres de las cuatro publicadas ese año. La versión de Vicente Rodríguez de Arellano de Las tardes de la granja merece una benevolente reseña anónima que se incluye en el apartado "Moral», y que justamente tiende a destacar ese valor en esta obra compuesta para la educación de los niños. Poco más, aparte del resumen de la estructura y el argumento, aporta esta reseńa (1804, tomo V, pp. 285-286). Olive firma la crítica de dos novelas francesas traducidas y editadas en 1803, El inglés en la India, o la cabaña indiana y Atala, y de otra publicada en este mismo ańo de 1804, Lorimon. En su pluma la reseña no es sólo la recensión de los contenidos y el repaso convencional de conceptos poéticos establecidos, sino que se convierte ya en un ejercicio de crítica literaria moderna, que trasciende el texto reseñado para ofrecer una valoración de más alto alcance.

También el género novelesco ha cambiado. Olive reseña novelas de SaintPierre, de Chateaubriand, de Baculard d'Arnaud, y lo que despertará el interés del crítico no serán necesariamente los valores que destacaban una o dos décadas atrás. Si todavía en Lorimon lo que pone de relieve Olive es el componente moral es porque su autor es el apóstol de la moralidad: «Pero viniendo a Lorimon, diremos que la idea de la obra nos ha parecido moral, y que puede ser útil a los que tengan valor para leer sus tan pesadas y tan obvias reflexiones» (1804, tomo VI, p. 202). Otra cosa es Atala. Sus puntualizaciones sobre la verosimilitud en el tratamiento de los personajes o de adecuación del estilo a su condición revelan aún una perspectiva poética plenamente neoclásica, pero la obra de Chateaubriand es enjuiciada con unas pinceladas casi impresionistas que ponen de manifiesto tanto los nuevos rumbos de la novela en Europa como las nuevas formas de acercarse a una obra literaria, más desde el gusto y la emoción que provocan en el lector que desde los cánones de una poética establecida: «Así pues lo que creo forma el mérito de este poema es la animada expresión de los sentimientos, algunas buenas comparaciones, ciertas imágenes muy apropiadas, la sensibilidad y ternura que todo él respira, y las felices imitaciones de los buenos autores antiguos, que en efecto se conoce ha manejado el autor» $\left(1804\right.$, tomo VI, p. 254) ${ }^{44}$.

44. Obsérvese el detalle del uso de la primera persona del singular, muy indicativo de la creciente personalización de la reseña crítica. 
Pero quizá lo que más distingue estas reseñas críticas de la nueva etapa del Memorial, al menos tal y como las concibe Olive, es que empieza a considerarse indispensable en ellas el elemento histórico literario. La crítica propiamente dicha de Lorimon se reduce a la frase arriba citada y al elogio de la traducción hecha por el sucesor de Olive en la redacción del periódico, José María de Carnerero; el resto lo ocupa el repaso de la extensa producción del autor, Baculard d'Arnaud, y la valoración nada benévola de este dramaturgo, novelista y poeta al que Olive considera «el corifeo de los autores de dramas lúgubres y novelas espantosas», que con su «imaginación desarreglada» $\mathrm{y}$ su gusto por el horror ha convertido el teatro "en una carnicería o en un hospital» con obras escritas «en un estilo descuidado, y aquella jerga de expresiones vagas e hinchadas que aturden, pero nada dicen» (200-202) ${ }^{45}$. Otro tanto sucede en la extensa reseńa de El inglés en la India, que antes de centrarse en el comentario de la novela corta de Bernardin de Saint-Pierre, repasa otras obras del autor, en especial su celebérrima Pablo y Virginia, traducida al español unos años antes.

Otro elemento característico de las críticas de Olive es la intervención directa, casi creativa, en la obra reseñada. De Atala Olive reseńa la traducción recién editada en Valencia en $1803^{46}$, pero aparte de una valoración muy general sobre la calidad de las dos versiones españolas existentes hasta el momento, la atención del periodista se dirige hacia la obra original, hacia el texto de Chateaubriand; es éste el que comenta ampliamente, no la versión realizada para el público espańol. Y cuando se trata de ofrecer a los lectores del Memorial una muestra de la variedad de estilos de la novela y de sus momentos más logrados (diez páginas de una reseña de quince), no son fragmentos de la traducción de Ródenas lo que transcribe Pedro Olive, sino su propia traducción, realizada al efecto. En El inglés en la India la intervención es de otro tipo pero igualmente significativa: el largo resumen que contiene la reseńa no es un extracto convencional del argumento, a la manera en que se ha hecho durante todo el XVIII, sino un texto del propio reseñador, es decir, un resumen recreado literariamente por Olive, que ya estaba acostumbrado a esta labor de semi-creación o re-creación, pues unos años atrás, en su miscelánea Las noches de invierno había resumido,

45. Injusta crítica la de Olive, porque a pesar de la opinión que le merece la obra del autor francés no había tenido inconveniente en aprovecharse de parte de ella. En su miscelánea Las noches de invierno (1796-1797) aparecen compendiadas varias novelas de las colecciones Épreuves du sentiment y Délaissements de l'homme sensible.

46. Se trata de la versión de Pascual Genaro Ródenas, según se deduce de las siglas que figuran en la dedicatoria. 
compendiado y reelaborado varias novelas y relatos de diferente extensión y procedencia.

En 1805 Pedro María de Olive ya no está en el periódico, pero la actitud ante la novela y la factura de las reseñas continúan la línea iniciada por él. Con los nuevos responsables, los hermanos José María y Mariano de Carnerero, aumenta la presencia de la narrativa en el periódico, al tiempo que la crítica de la novela sigue el proceso de independencia de los patrones canónicos practicados durante el siglo XVIII, con el repaso más o menos sistemático de las categorías establecidas, y se va convirtiendo en una crítica cada vez más personal y más variada en sus formatos.

En los cuatro tomos de ese año 1805 se reseñan en el Memorial literario la ya mencionada Williams y Juanita, de Kotzebue; El viaje de un filósofo a Selenópolis, utopía traducida por Antonio Marqués y Espejo y publicada en 1804; Oderay, novela anónima en la línea del exotismo costumbrista que había introducido en la narrativa europea la Atala de Chateaubriand, y que traduce Gaspar Zavala y Zamora en 1804; la colección de novelas El Decamerón español de Vicente Rodríguez de Arellano, y la novela de aventuras de Jerónimo Martín de Bernardo El Emprendedor, ambas publicadas en este año de 1805 . Mención aparte merece la polémica que se inició en el número de julio de ese año a raíz de la publicación de El Anti-Quijote, y que dio lugar a varias réplicas y contrarréplicas que recogió puntualmente el periódico madrileńo.

La reseña del Viaje de un filósofo a Selenópolis (Abril 1805, pp. 92-100) la firma José María de Carnerero y es una muestra más de cómo la crítica de estos ańos trasciende el enjuiciamiento del texto que en primera instancia se está reseñando para convertirse casi en un ensayo en el que el reseñador comenta cualquier aspecto que cree oportuno de historia o poética literarias. La crítica de esta traducción de Marqués y Espejo se inscribe en la de los libros de viajes imaginarios, con la referencia a los ya conocidos Viajes de Enrique Wanton y Viajes de Gulliver, un género que al reseñador no le parece digno de «ocupar el lugar preeminente en una biblioteca escogida» (94), aunque no deja de reconocer su utilidad social y moral: "No hay duda que de estos ideales viajes pueden muy bien hacerse aplicaciones muy útiles y concernientes a la prosperidad de todo lo bueno y provechoso, con detrimento de lo perjudicial y mal establecido. [...] dan ocasión en muchos de sus pasajes a corolarios muy útiles respecto de los que en la Europa nos llamamos pueblos civilizados y cultos» (93). En este sentido, de este viaje imaginario le parece a Carnerero especialmente provechoso el capítulo sobre la educación de los selenitas, algunos de cuyos principios señala a continuación. Pero la atención del reseñador se desvía inmediatamente de la 
novela cuando lee en el capítulo sobre el estado de la literatura en la nación selenita esta afirmación del autor: «El versificar cualquiera pieza dramática (dice el autor) es una manía de las más raras. En efecto, ¿`no es extraño que el poeta se tome el trabajo de rimar una pieza cuando el grande arte del actor al representarla consiste en hacer desaparecer del verso el consonante y la medida?» (96). No le hace falta más a Carnerero para lanzarse a una extensa respuesta a esta "rareza" de los selenitas que "decididamente se aparta de las reglas del buen gusto, establecidas y seguidas por los mejores maestros antiguos y modernos» y que encarrila la reseńa por derroteros que nada tienen ya de crítica novelesca sino de crítica teatral.

Unas páginas más adelante, en el mismo número de 1805, Mariano Carnerero, el hermano de José María, ofrece su crítica de Oderay. Usos, trajes, ritos y leyes de los habitantes de la América septentrional (abril 1805, pp. 166175). Es una interesantísima reseña que entra de pleno en la historia literaria del género novelesco. Sólo al final de su crítica se ocupa Mariano Carnerero de la obra reseńada, y de la traducción de Zavala y Zamora, que considera «bastante incorrecta y descuidada» (175), no por incapacidad del traductor, sino por precipitación y falta de la conveniente revisión. Al análisis de esta obra llega tras una historia del estado de la novela en Europa hasta que las figuras de Bernardin de Saint-Pierre y Chateaubriand renovaron el género con sus novelas Pablo y Virginia y Atala, modelos que se propuso imitar el autor de Oderay. El menor de los Carnerero repasa las orientaciones que impusieron en la novela europea del siglo XVIII las novelas inglesas, francesas y alemanas ("Todas las novelas que inundaron largo tiempo la Europa estuvieron reducidas a dos puntos: o a intrigas amorosas, o a sucesos terribles, lúgubres, y aun mágicos», 168), y que, a excepción de la producción del incuestionable Richardson, contribuyeron en manos de autores y traductores poco esmerados al "descrédito que en general tiene el género romancesco entre los amantes del buen gusto» (167). En esta situación se encuadra la gran aportación de Saint-Pierre a la novela moderna con Pablo y Virginia, "obra maestra que tantas y tan dulces lágrimas ha arrancado a los corazones sensibles» (169):

En efecto, abrió el camino a un nuevo género: en vez de inverosimilitudes, descripciones insípidas, sucesos sombríos, y lenguaje pomposo, resaltan en ella un orden perfectamente seguido en todo el plan, imágenes bellas y encantadoras, acaecimientos que aunque muy sencillos en sí, interesan y conmueven dulcemente; un lenguaje puro, armonioso y arreglado al carácter de cada personaje en particular. [...] Los amantes del buen gusto admiraron semejantes bellezas, y vieron renacer entre el tumulto de novelas insípidas e 
inmorales una producción propia para inspirar el amor a la virtud, y escrita con el tino y primor que se debe apetecer en todo género de composiciones. (169-170)

A juicio de Mariano Carnerero, la gran aportación de Saint-Pierre, como después la de Chateaubriand, no fue sólo la de proponer una nueva forma de novela, fruto de la renovación de una sensibilidad desprovista del patetismo, la moralidad y otras connotaciones dieciochescas, sino el hacerlo con novelas bien escritas y que en su factura respetan los principios del buen gusto, los que presidieron toda la estética de la época neoclásica. Conforme a estos criterios estéticos y al modelo que imita Oderay, valora Carnerero la novela recién editada en la versión española de Zavala y Zamora; hay en ella, estima el crítico, «rasgos verdaderamente poéticos, imágenes análogas a las situaciones y reflexiones filosóficas» (173), como muestra de los cuales ofrece un pasaje, para que los lectores conozcan el estilo de la novela.

Más allá del entusiasmo por los dos novelistas franceses, que ya había manifestado Olive en sus reseñas de Atala y El inglés en la India en 1804, la reseńa de Mariano Carnerero muestra que los cambios de la novela en esta primera década del siglo XIX producen cambios en los modos de juzgarla, y que los criterios de la nueva generación de reseñadores del Memorial literario combinan los referentes de la estética neoclásica con los de una nueva sensibilidad literaria que camina hacia el romanticismo ${ }^{47}$.

Menos interés tiene la reseńa de los dos primeros tomos de la colección El Decamerón español, de Vicente Rodríguez de Arellano, firmada por F.C. (septiembre 1805, pp. 340-364). Apelando también al buen gusto, considera las ocho novelas editadas "curiosas y entretenidas», y dotadas de la pertinente dosis de moralidad. Otra cosa es su estilo, que se resiente de una traducción excesivamente literal, cuando no errada, como muestran algunos ejemplos que desgrana voluntariosamente este crítico que asume con cierta timidez la función de orientadora de los escritores por los rectos caminos del arte literaria:

No quisiéramos pasar plaza de rígidos censores, pero no podemos dejar de decir que hay algunas frases cuyo sentido es preciso adivinar, y aun otras que es imposible haya sucedido lo que dicen. [...] pudiera ser más correcto el lenguaje de esta obra; y si su autor sabe manejar nuestra lengua con mucha gracia, como lo tiene acreditado en

47. Sobre las nuevas ideas en el terreno de la poética que sin duda incidieron en estos cambios en las actitudes críticas, véase el esclarecedor trabajo de $\mathrm{M}^{\mathrm{a}}$ José Rodríguez Sánchez de León, "La teoría del gusto y la constitución del realismo burgués en el siglo XVIII», Res publica, 23, 2010, pp. 37-55. 
bastantes dramas que ha escrito para el teatro, ¿quién mejor que él puede corregir estos defectos, con tanta más razón cuanto es más fácil escribir en prosa que en verso? Es constante que el señor Arellano no necesita de nuestras advertencias, y que si hemos notado estos lunares de su obra, ha sido por cumplir la obligación que nos hemos impuesto. (342-344)

No hay verdadero juicio en esta reseña, más allá de la puesta en evidencia de esos "lunares» en el estilo. Su interés radica en avanzar en una dirección emprendida por el Memorial literario años antes: la de ofrecer cada vez más y más extensos pasajes de las obras analizadas. Cuando se contempla el conjunto de la publicación en este año de 1805 resulta evidente el propósito de los memorialistas de dar más cabida a los textos narrativos. El anónimo F.C. no se limita a seleccionar un pasaje de la obra reseñada que sirva de muestra de sus valores estilísticos, como habían hecho otros críticos, sino que ofrece una versión compendiada de una de las anécdotas que forman la colección, Ningún hombre quiere así, que ocupa veinte páginas de ese número del Memorial ${ }^{48}$.

La última reseña de este año 1805 se publica en septiembre (pp. 364374), y versa sobre la novela El Emprendedor, o Aventuras de un español en el Asia, de Jerónimo Martín de Bernardo. Adopta la forma de una carta dirigida a los editores del Memorial literario por un tal Cándido Faura, suscriptor del periódico que escribe desde Cuenca. La reseña ha sido comentada por Joaquín Álvarez Barrientos en su edición de la novela ${ }^{49}$, por lo que no entraré aquí en un análisis pormenorizado de las opiniones de Faura. Baste señalar, en consonancia con el hilo central de este trabajo, que la reseña de Cándido Faura abre la crítica del Memorial en esta tercera etapa a nuevas formas y estilos: la carta enviada al periódico por un suscriptor, el tono irónico y la ambigüedad buscada en unos juicios que en cierto modo son muy indicativos de la desorientación que sigue provocando todavía en algunos críticos la novela. Por eso, lo más interesante de esta reseńa es que confronta dos estéticas, "una, la de Boileau y Horacio, que le gusta más, y otra, más moderna, que se basa en la observación de la naturaleza, agreste, variada y confusa, que presenta diversas perspectivas, que también parece gustarle, aunque se refiera a ella con ironía, como ejemplo de la poética

48. La novelita se encuentra en el tomo II de El Decamerón español, Madrid, Gómez Fuentenebro y Compañía, 1805, pp. 172-226.

49. Joaquín Álvarez Barrientos, «Introducción» a El Emprendedor, o Aventuras de un español en el Asia, Alicante, Instituto de Cultura Juan Gil-Albert y Diputación de Alicante, 1998, pp. 9-110. La reseña del Memorial literario aparece reproducida en las pp. 366-371 de esta edición. 
nueva» ${ }^{50}$. Tengo mis dudas sobre este último punto. Las reseñas de Olive y de los Carnerero publicadas este mismo año en el Memorial habían mostrado la aclimatación de esa nueva estética que exalta el genio del artista capaz de crear obras todavía acordes con los principios del buen gusto; esta reseńa de Cándido Faura, que lleva a Boileau en una mano y a Horacio en la otra, es, a mi juicio, simplemente y con varias capas de ironía, el rechazo de la originalidad, la imaginación, y la sublimidad en el terreno de la novela, y la burla de la crítica que las defiende ${ }^{51}$.

En la presentación de las reseñas de novelas en el Memorial literario en 1805 he dejado en último lugar la mención de El Anti-Quijote, un texto de crítica sobre la novela cervantina. La obra de Nicolás Pérez fue motivo de una viva polémica librada en las páginas de este periódico por la pretensión de su autor de poner en evidencia los errores e imperfecciones del Quijote mediante un análisis crítico del mismo, lo que se consideró una impertinencia y un delito de leso patriotismo literario que levantó muchas voces en defensa de la obra cervantina. Fueron los primeros en reaccionar los redactores del Memorial, quienes en su número de julio de 1805, en el apartado de "Crítica», publicaron un Examen del Prospecto de la obra crítica titulada el Anti-quixote (pp. 159-174), que reproducía el 'Prospecto' en cuestión, y en el que, animados por la obligación patriótica de «defender las producciones que la han dado gloria inmortal» (160), los memorialistas van rebatiendo cada una de las afirmaciones de Nicolás Pérez. La reacción de éste no se hizo esperar, y llegó en forma de "Carta a los editores del Memorial Literario sobre la censura que han hecho del Prospecto de la obra del Anti-Quixote» (pp. 220-232), enviada por «El admirador eterno del Setabiense» y firmada en Madrid el 14 de agosto. Sucesivos números del periódico fueron dando

50. Ibid, p. 98.

51. Quizá es necesario leer la carta completa para percibir el tono irónico de todo el texto y la burla implícita de cada una de las afirmaciones de quien lo escribe, pero baste este párrafo: «Dirán también algunos Aristarcos insufribles que en esta novela se quebrantan a cada momento las reglas del buen gusto y del arte; y bien, ¿̨qué importa todo esto? [...] Nada, nada; lo mejor de todo es dejar correr la imaginación, para que luego los Jueces imparciales comparen la obra a la Naturaleza agreste, que en su mismo desorden y confusión presenta mil perspectivas asombrosas y magnificas. ¿Quién sabe lo que lisonjean estas comparaciones? ¡Ah, acéfalos insipientes, a quienes no es dado conocer el mérito y satisfacción del señor Don Jerónimo! [...] ¡qué momentos aquellos en que al acabar alguna de sus vivas y animadas descripciones tomadas de la misma Naturaleza, se quedase enajenado de placer. [...] Trabajillo me ha costado el confesar que no lo entendía: [...] jes tan sublime el lenguaje del Emprendedor!» (pp. 368-370). Las cursivas son del texto, e indican en muchos casos los préstamos tomados de esa nueva crítica que parodia. 
a la luz las opiniones de cuantos quisieron intervenir en esta discusión literaria ${ }^{52}$.

El análisis de estos textos y de los argumentos de quienes los escribieron desbordan los límites de este trabajo, pero su somera presentación nos sirve para ilustrar dos ideas. Por un lado, cómo la crítica, que ha ido perfilando a lo largo del siglo XVIII sus competencias y objetivos, debate ahora, ante un texto canónico e incuestionado, sobre sus propios límites ${ }^{53}$. Por otro lado, que en unos pocos años la novela ha ido ganando presencia en el Memorial literario con escritos y enfoques críticos e histórico literarios inimaginables en el momento en que lo fundaron Ezquerra y Trullenc.

Esta última consideración se fundamenta también en el propósito manifestado por los redactores de esta última etapa de amenizar la publicación con la oferta de textos narrativos. Al aumento de los extractos y fragmentos de las novelas analizadas hay que sumar desde 1804 la inclusión de cuentos, anécdotas, hechos curiosos, y otras muestras de la narrativa breve de la época, con lo que el Memorial se incorpora en esta etapa decimonónica a la lista de publicaciones periódicas que, ya desde los años de Nipho, había acogido este tipo de textos ${ }^{54}$.

Esta voluntad de consolidar la oferta lectora en el terreno de la narrativa -como ya se daba, por ejemplo, con los textos poéticos- se manifestó en 1806 en la declaración que precedía el resumen de la novela alemana Las víctimas de la magia, de la que ya he hablado. En esa "Advertencia» escribían los responsables del Memorial:

52. En este tomo III de 1805 se publican a continuación una Carta firmada por A.M.D. (septiembre, pp. 285-289); otra en el mismo número remitida por A.D.L.T (pp. 290-295). En el tomo IV de ese año se publica un texto muy extenso, también en forma de carta, fechada en Marsella el 2 de agosto de 1805 y sin firma (octubre, pp. 9-29 y 63-80). Por otro lado, hay que señalar que la obra de Cervantes ya había sido objeto de controversia en el Memorial literario. En diversos números de 1788 (septiembre, pp. 130-146, octubre, pp. 339-352, noviembre, pp. 435-445) se publicó una «Defensa de Miguel de Cervantes e impugnación del $\mathrm{n}^{\circ} 4$ y 5 de la obra periódica intitulada Gabinete de Lectura española», contra la sugerencia de Isidoro Bosarte de que la novela Rinconete y Cortadillo no era del todo creación original de Cervantes.

53. «Analizar críticamente las obras es empresa digna de un literato; pero el querer denigrar las que juzgan como maestras es propio de un deseo de singularizarse, de una pedantería audaz y de una ignorancia suma», escriben los memorialistas en su "Examen del Prospecto..." de Nicolás Pérez, p. 161.

54. La bibliografía sobre la presencia de la narrativa breve en la prensa dieciochesca es amplia, por lo que me limitaré a citar dos de los estudios de conjunto más recientes, en donde el lector interesado podrá encontrar amplia información bibliográfica: Borja Rodríguez Gutiérrez, Historia del cuento español (1764-1850), Madrid, Iberoamericana, 2004, y Marieta Cantos Casenave, Antología del cuento del siglo XVIII, Madrid, Cátedra, 2005. 
Deseosos los editores de este periódico de corresponder en todo a la buena acogida que merecen al público en su empresa, han determinado para dar a su obra más amenidad, no perdiendo jamás la utilidad de vista, dar una noticia de varias novelas extranjeras, dignas de ser conocidas. Para esto procurarán presentar o los extractos insertos en los periódicos extranjeros, o hacerlos ellos por sí, siempre que puedan, en virtud de un detenido examen. Así es que observando el objeto de la novela que se extracte, y el influjo que pueda tener en las costumbres públicas o particulares, se formará una colección de novelas que a más del placer que proporcione en su lectura, tendrá el mérito de no ser infructuosa, y de estar a los alcances universales, siendo de esta manera mayores las ventajas que de ella resulten (abril 1806, pp. 128-129).

Lamentablemente no hubo ocasión de desarrollar este proyecto de una "colección de novelas", pero es muy indicativo de la rápida respuesta de los responsables del Memorial literario al éxito editorial de la novela en la España del inicio del siglo XIX y de su apuesta por una nueva forma de periodismo literario: la prensa antológica, que tan extraordinario desarrollo tendría en ese siglo.

\section{HACIA LA CONSTRUCCIÓN DE UN MODELO DE CRÍTICA NOVELÍSTICA}

A lo largo de cincuenta y dos números durante casi un cuarto de siglo fueron muchas las voces que se pronunciaron sobre la novela en el Memorial literario, y no es posible, por tanto, reconstruir un discurso único y homogéneo sobre una producción muy amplia en la que también se dio la diversidad y la evolución. Las líneas maestras del tratamiento de la novela en cada una de las etapas del periódico han sido analizadas e ilustradas en el cuerpo de este trabajo, que ha querido indagar sobre dos cuestiones esenciales: el concepto de novela que transmitió esta publicación y la construcción de un modelo crítico para enjuiciar este género.

No era previsible que los críticos del Memorial literario se apartaran del concepto de novela dominante en la España del siglo XVIII: un género que había de ganarse su carta de ciudadanía literaria garantizando al menos su utilidad y sus valores morales. Pero es tan notable el cambio que van experimentando estos conceptos a finales del siglo que por fuerza ha de reflejarse en las valoraciones de los memorialistas. En los años ochenta predominan aún un criterio de utilidad ligado a la educación, a la instrucción pedagógica y moral, y un sentido de lo moral eminentemente religioso. Por 
eso, se le dice al lector que la novela reseñada es útil porque enseña geografía o historia, o porque avisa sobre los peligros de la Corte, se recalcan las máximas y consejos morales que contiene, se subraya que inspira sentimientos acordes con la moral cristiana, y que su objetivo es hacer amable la virtud y aborrecible el vicio. Nada muy alejado de lo que escribiría un censor atento a la salvaguarda de la moral y las buenas costumbres. Todavía en la década de 1790 podemos encontrar esa idea de una novela que da lecciones a los padres, a los jóvenes de ambos sexos, a los esposos, pero asistimos a un desplazamiento paulatino de los conceptos de utilidad y moral a un plano más social. Por ello, vemos que los críticos tienden a destacar los valores de una ética civil en novelas que proponen nuevos modelos sociales y favorecen una reflexión crítica sobre las costumbres. La novela es útil si ayuda a observar y corregir los vicios sociales y a explorar los sentimientos; no es ya entendida como una guía moral, sino como un instrumento intelectual y emocional de análisis de los comportamientos personales y sociales. Los nuevos modelos de novela llegados sobre todo de Inglaterra en esta década final del siglo, ligados a la orientación civil de la filosofía moral de aquel país, imponen un nuevo concepto de novela que la crítica no deja de transmitir a los lectores.

Cuando en 1806, en la última reseña novelística del Memorial, se anuncia el proyecto de una colección de novelas extranjeras cuya utilidad vendrá determinada por «el influjo que pueda tener en las costumbres públicas o particulares» cada novela extractada, se ha dado ya carta de naturaleza a una novela cuya utilidad moral es de índole eminentemente civil, no muy alejada de la que tenía el teatro para la generación ilustrada. Logra así el Memorial literario, al final de su andadura, un modelo de crítica de la novela civil y secularizada, como lo fue la crítica teatral y que, por tanto, puede aspirar, como ella, a proponer a los lectores modelos de sociedad, como lo hacen las propias novelas que se analizan ${ }^{55}$.

Esta concepción de la novela en la que lo moral se impone sobre cualquier otra consideración supone la postergación del elemento estético, que sin embargo va ganando espacio en la apreciación de la novela y por tanto en su concepción. No es ajeno a esta evolución el cambio en la orientación del periódico desde la reapertura de 1801, cuando sus responsables lo llevaron por derroteros más literarios, acercándolo a otras publicaciones coetáneas como Variedades de ciencias, literatura y artes o Minerva. La nueva generación de críticos, escritores ellos mismos en algunos casos, comprende muy bien que una novela es una producción literaria, en la que ha de valorarse tanto

55. Véase Inmaculada Urzainqui, "Crítica teatral y secularización: el Memorial Literario (1784-1797)», op. cit. 
su contenido como su estilo ${ }^{56}$. Cada vez les parece más importante que las novelas estén bien escritas; por eso, con criterios estilísticos valoran ( $\mathrm{La}$ Serafina) o condenan (Lecturas útiles y entretenidas) las novelas que juzgan, y por eso en las reseñas de la última etapa del Memorial prima la valoración estética sobre la moral. De novelas como Atala, como Pablo y Virginia, como Oderay, no se cansan los críticos de ensalzar «las bellas imágenes y el sublime lenguaje», las «imágenes bellísimas», el «lenguaje puro, vivo, apasionado, lleno de hermosas imágenes» o "los rasgos verdaderamente poéticos». Desde ese creciente criterio estético puede interpretarse también el deseo de ofrecer pasajes de las obras reseñadas: el crítico quiere transmitir al lector esos valores, quiere hacerle degustar el placer estético que ha provocado la novela en el propio reseńador. «Ojalá las personas sensibles hallen tanto placer en leer estos trozos cual nosotros hemos tenido en traducirlos» (1804, tomo VI, p. 265), dice Olive al introducir en su reseńa de Atala un extenso pasaje de la novela.

Este tipo de valoraciones suponen, desde luego, tanto cambios en los modelos narrativos como un nuevo perfil del crítico. De ser alguien que no ha leído las novelas que, por así decir, reseña, y se declara incapaz de enjuiciarlas, el crítico de la nueva generación se nos presenta como un hombre con conocimientos literarios, que opina con autoridad sobre teoría e historia literaria, que tiene un bagaje notorio de lecturas novelescas, que conoce la literatura española y se asoma con soltura a la extranjera. Alguien que manifiesta un concepción muy moderna de la crítica, que no sólo debe enjuiciar desde la normativa poética vigente, sino desde la emoción estética que produce la obra, que es, por otro lado, personal y única en cada texto literario. En este sentido, se aprecia con toda claridad cómo la crítica normativa de las dos primeras etapas del Memorial da paso en la etapa decimonónica a una forma de crítica novelística que, sin renunciar a los criterios de valoración convencionales (sigue hablándose de composición, de personajes, de verosimilitud), enjuicia las obras de manera más individualizada y se enfrenta a ellas con una mirada más personal, comentándolas sobre todo desde los efectos que ha tenido en el reseñador la lectura de la novela ${ }^{57}$.

56. El reseñador del Decamerón español escribe: «Dos cosas hay que mirar en las obras de esta clase: la primera, si los hechos que contienen son tales que deban publicarse, y la segunda, si están escritos del modo que debieran escribirse. Es decir, que en lo primero luce el buen gusto y la sana moral del escritor, y en lo segundo se conoce su buen o mal estilo; pero como cualquiera de estas dos circunstancias que falte es suficiente para desacreditar la obra, así es que a las dos debe atender igualmente el que ha de criticarla en un periódico, cuyo fin es el de dar a conocer el verdadero mérito del libro nuevo» (septiembre 1805, p. 340).

57. Aunque como bien estudia Inmaculada Urzainqui la crítica teatral del Memorial «se 
Cada reseńa de novela es única y diferente en la última etapa del Memorial; cada reseñador se fija en lo que le llama la atención de una novela, señala lo que le gusta o lo que no le gusta, en una crítica que páginas atrás he calificado de impresionista, y que supone una liberación de patrones establecidos. Las reseñas suelen ir firmadas, son ejercicios personales de valoración que, por otro lado, muestran cómo se han ensanchado los límites de la reseña crítica. De los anuncios-reseña poco más que descriptivos de los años ochenta, hemos pasado a reseñas que se revelan casi como un ensayo que trasciende el propio texto comentado y en el que caben opiniones y valoraciones sobre cualquier aspecto de historia literaria. Es un rasgo más de la modernidad de estas críticas que el Memorial compartió con otros periódicos y que parecen indicar, por tanto, los nuevos rumbos de la crítica literaria periodística.

La polifonía de voces en las páginas del Memorial literario no permite, es cierto, ofrecer una imagen fija de la novela en Espańa en el siglo XVIII, pero la propia historia interna del periódico madrileño y su emplazamiento privilegiado en unas décadas de importantes cambios en la historia literaria española nos brindan una imagen mucho más rica. Es una imagen cambiante y movediza, sí, pero real, porque refleja la evolución de esa producción editorial que en menos de treinta ańos ofreció a los lectores españoles una muestra de todas las tendencias narrativas del siglo. Si la evolución de la novela fue marcando en buena medida las pautas nuevas necesarias para enjuiciarla, también parece evidente que la labor de los críticos del Memorial literario tuvo su papel en la transición hacia nuevas formas literarias, al poner de relieve en sus reseñas valores que doscientos años después siguen constituyendo la esencia del género novela.

articula como una labor de grupo", puede apreciarse en ella un proceso más o menos paralelo de personalización de la crítica dramática. "Crítica teatral y secularización...», op. cit., p. 211. 